p-ISSN: $2338-4794$

e-ISSN: 2579-7476

Vol.9. No. 1 Januari-April 2021

\title{
KINERJA KEUANGAN PT BLUE BIRD TBK
}

\author{
Viraisya Haninda Drana Wasistha ${ }^{1)}$ \\ 1) Dit. Bina Perencanaan Tata Ruang Daerah Wilayah II, Kementerian ATR/BPN \\ viraisyahnnd@gmail.com \\ Deni Herdiyana ${ }^{2}$ \\ 2) Politeknik Keuangan Negara STAN \\ deni.herdiyana@pknstan.ac.id
}

\begin{abstract}
This research was conducted to analyze the financial performance of PT Blue Bird Tbk based on financial ratios consisting of liquidity ratios, solvency, activity, and profitability. The research method used is through a quantitative approach. To support this research, data methods were carried out which included literature study and data analysis. The results of the study can be concluded that the liquidity and solvency ratio of PT Blue Bird Tbk is quite good. However, the company's activity and profitability ratios show a poor rating compared to the industry average
\end{abstract}

Keywords: Liquidtity ratio, solvency ratio, activyty ratio, and profitability ratio

\section{PENDAHULUAN}

Di Indonesia, kemunculan transportasi berbasis aplikasi online mulai marak sejak tahun 2014 dengan hadirnya aplikasi grab yang berasal dari Malaysia dan uber dari Amerika Serikat. Setelah itu, disusul dengan peluncuran aplikasi transportasi online karya anak bangsa bernama gojek pada tahun 2015. Sejak awal kemunculannya, transportasi online dapat dengan mudah diterima oleh masyarakat karena berbagai kelebihan yang ditawarkan, seperti kemudahan untuk melakukan pemesanan melalui aplikasi dan harga yang bersaing dengan transportasi konvensional.

Pada saat pendiri dan pengemudi transportasi online mencapai kesuksesan, hal berbeda justru dialami oleh para pemberi jasa transportasi konvensional, misalnya pengemudi ojek dan taksi konvensional. Mereka kehilangan para pelanggannya, sehingga pendapatan yang diperoleh menurun drastis semenjak banyaknya masyarakat yang beralih menggunakan transportasi online.

PT Blue Bird Tbk merupakan salah satu dari sekian banyak perusahaan taksi konvensional yang mengalami penurunan pendapatan dikarenakan kemunculan transportasi online. Berdasarkan data yang diperoleh dari laporan tahunan PT Blue Bird Tbk, pendapatan neto yang dihasilkan pada tahun 2015 adalah sebesar Rp5,4 triliun atau meningkat sebesar 14,9\% dari tahun 2014, sedangkan pada tahun 2016 pendapatan neto perusahaan menurun hingga 12,4\% menjadi Rp4,7 triliun. Penurunan tersebut terjadi hingga tahun 2017 dengan pendapatan neto sebesar Rp4,2 triliun atau turun sebesar $10,6 \%$ dibandingkan tahun sebelumnya.

Menurut penelitian terdahulu yang dilakukan oleh Rakhmanita dan Anggarini (2018), kinerja PT Blue Bird Tbk pada tahun 2014-2016 yang dinilai dengan rasio profitabilitas menunjukkan adanya gross profit margin, net profit margin, return on assets, dan return on equity yang tidak efisien. Rasio profitabilitas merupakan salah satu rasio yang mengukur kemampuan perusahaan dalam menghasilkan keuntungan sebagai suatu bentuk pengukuran kinerja keuangan perusahaan.

Dalam penelitian lain pada tahun yang berbeda, kesimpulan yang dihasilkan 
juga serupa. Selama tahun 2015-2017, rasio profitabilitas PT Blue Bird Tbk yang diukur melalui indikator gross profit margin, net profit margin, dan return on equity cenderung mengalami penurunan yang disebabkan oleh laba dan penjualan yang juga menurun. Ketiga indikator tersebut jika dibandingkan dengan standar industri juga masih berada di bawah standar. Oleh karena itu, tingkat profitabilitas PT Blue Bird Tbk dapat dikatakan berada pada kondisi kurang baik. (Goni, et al, 2019).

Penurunan pendapatan taksi konvensional menyebabkan banyak pengemudi taksi Bluebird beralih profesi menjadi pengemudi taksi online. Dilihat dari segi bisnis, hal tersebut tentu dapat mengancam keberlangsungan proses bisnis di PT Blue Bird Tbk yang sangat bergantung pada jumlah armada taksi yang dapat beroperasi.

Dalam keterpurukan tersebut, PT Blue Bird Tbk merespons dengan mengambil langkah melalui kerja sama dengan Gojek pada awal tahun 2017. Menurut laporan tahunan, PT Blue Bird Tbk memulai kolaborasinya dengan Gojek sejak tanggal 1 Februari 2017 dengan hadirnya taksi Bluebird yang dapat dipesan melalui aplikasi GO-CAR. Kerja sama kedua perusahaan transportasi itu berlanjut pada tanggal 30 Maret 2017 ketika diluncurkannya layanan baru bernama GOBLUEBIRD pada aplikasi Gojek.

Kerja sama tersebut diharapkan mampu membawa dampak positif bagi PT
Blue Bird Tbk berupa peningkatan pada pendapatan yang dihasilkan. Hal tersebut juga berpotensi menyebabkan adanya perubahan dalam kondisi keuangan perusahaan secara keseluruhan di masa depan. Berdasarkan fakta dan fenomena yang telah diuraikan, perlu untuk dianalisis kinerja keuangan PT Blue Bird Tbk tahun 2016-2018 yang diukur dengan menggunakan rasio-rasio keuangan.

Tujuan penelitian ini antara lain: 1). Untuk menganalisis rasio likuiditas, solvabilitas, aktivitas, dan profitabilitas pada PT Blue Bird Tbk tahun 2016-2018. 2). Untuk menganalisis kinerja keuangan PT Blue Bird Tbk pada tahun 2016-2018 berdasarkan rasio keuangan.

\section{LANDASAN TEORI}

\section{Rasio lancar}

Rasio lancar (Current ratio) merupakan rasio yang digunakan untuk mengukur mampu atau tidaknya perusahaan dalam melunasi kewajiban jangka pendek atau utang yang dalam waktu dekat akan ditagih secara keseluruhan karena telah jatuh tempo. (Kasmir 2019). Rasio lancar menjelaskan seberapa banyak aktiva lancar yang tersedia untuk menutupi kewajiban jangka pendek yang akan jatuh tempo. Rasio lancar dihitung dengan membandingkan total aktiva lancar (current assets) dengan total utang lancar (current liabilities). Rumus yang digunakan untuk mencari rasio lancar adalah sebagai berikut:

$$
\text { Rasio Lancar }=\frac{\text { Aktiva Lancar }}{\text { Utang Lancar }}
$$

Berdasarkan perhitungan yang telah dilakukan, rasio lancar atau current ratio pada tahun 2017 meningkat cukup signifikan dibandingkan dengan tahun 2016 yang semula $108,38 \%$ menjadi $176,91 \%$ pada akhir tahun 2017. Kemudian, pada tahun 2018, rasio lancar perusahaan menurun menjadi $174,28 \%$.
Jika dilihat pada tabel 1, meskipun pada tahun 2018 aktiva lancar meningkat sebanyak 38,87\%, juga terjadi kenaikan yang lebih tinggi pada utang lancar sebesar $41,07 \%$. Hal tersebut menyebabkan turunnya rasio lancar perusahaan pada tahun 2018 yang berarti terjadi penurunan terhadap kemampuan perusahaan untuk 
membayar utang yang segera jatuh tempo dengan menggunakan aktiva lancar.

Tabel 1: Current Ratio PT Blue Bird Tbk

\begin{tabular}{ccrcr}
\hline \multirow{2}{*}{ No. } & \multirow{2}{*}{ Uraian } & \multicolumn{3}{c}{ Tahun } \\
\cline { 3 - 5 } & & $\mathbf{2 0 1 6}$ & $\mathbf{2 0 1 7}$ & $\mathbf{2 0 1 8}$ \\
\hline 1 & Current Assets & 882.304 & 771.222 & 1.071 .773 \\
2 & Current Liabilities & 814.103 & 435.947 & 614.987 \\
3 & Current Ratio (\%) & $108,38 \%$ & $176,91 \%$ & $174,28 \%$ \\
\hline
\end{tabular}

Sumber: Diolah dari laporan keuangan PT Blue Bird Tbk

Pada tahun 2016 rasio lancar adalah sebesar $108,38 \%$. Hal tersebut berarti jumlah aktiva lancar yang dimiliki perusahaan sebanyak 1,0838 kali utang lancar atau setiap Rp1 utang lancar dijamin perusahaan dengan Rp1,0838 aktiva lancar. Jadi perbandingan antara aktiva lancar dengan utang lancar adalah 1,0838:1. Pada tahun 2017 terjadi kenaikan rasio lancar menjadi sebesar $176,91 \%$. Hal tersebut berarti Rp1 utang lancar dijamin perusahaan dengan Rp1,7691 aktiva lancar dan perbandingan antara aktiva lancar dengan utang lancar adalah 1,7691:1. Selanjutnya, pada tahun 2018 rasio lancar menurun, tetapi tidak signifikan yaitu menjadi $174,28 \%$ yang berarti jumlah aktiva lancar sebanyak 1,7428 kali utang lancar atau setiap Rp1 utang lancar dijamin perusahaan dengan Rp1,7428 aktiva lancar.

\section{Rasio kas}

Perusahaan dapat mengetahui seberapa besar uang yang dimiliki dan siap digunakan untuk membayar utang tanpa perlu menjual atau menagih utang lancar lainnya dengan menggunakan rasio kas. Rasio kas (cash ratio) menurut Kasmir (2019) merupakan "alat yang digunakan untuk mengukur seberapa besar uang kas yang tersedia untuk membayar utang". Ketersediaan tersebut dapat ditunjukkan dari tersedianya dana kas atau setara kas seperti rekening giro atau tabungan di bank yang dapat ditarik setiap saat. Rumus yang digunakan untuk mencari rasio kas adalah sebagai berikut:

$$
\text { Rasio Kas }=\frac{\text { Kas dan Setara Kas }}{\text { Utang Lancar }}
$$

Rasio kas pada tahun 2016 adalah sebesar $72,7 \%$. Hal tersebut berarti setiap Rp1 utang lancar dijamin dengan kas, bank, dan setara kas (deposito berjangka yang dapat segera dijadikan kas) sebesar Rp0,727. Jadi perbandingan antara kas dan setara kas dengan utang lancar tahun 2016 adalah 0,727:1. Pada tahun 2017, rasio kas meningkat menjadi $108,8 \%$ yang berarti setiap Rp1 utang lancar perusahaan dijamin dengan kas dan setara kas sebesar
Rp1,088. Perbandingan kas dan setara kas dengan utang lancar pada tahun 2018 adalah 1,088:1. Rasio kas tahun 2018 mengalami penurunan menjadi $93,64 \%$. Hal tersebut menunjukkan kemampuan perusahaan menjamin Rp1 utang lancar yang dimiliki dengan Rp0,9364 kas dan setara kas. Perbandingan yang dihasilkan antara kas dan setara kas dengan utang lancar 2018 adalah 0,9354:1. 
Tabel 2: Cash Ratio PT Blue Bird Tbk

\begin{tabular}{clccc}
\hline \multirow{2}{*}{ No. } & \multirow{2}{*}{ Uraian } & \multicolumn{3}{c}{ Tahun } \\
\cline { 3 - 5 } & & $\mathbf{2 0 1 6}$ & $\mathbf{2 0 1 7}$ & $\mathbf{2 0 1 8}$ \\
\hline 1 & Cash and Cash Equivalent & 591.886 & 474.289 & 575.900 \\
2 & Current Liabilities & 814.103 & 435.947 & 614.987 \\
3 & Cash Ratio $(\%)$ & $72,70 \%$ & $108,80 \%$ & $93,64 \%$ \\
\hline
\end{tabular}

Sumber: Diolah dari laporan keuangan PT Blue Bird Tbk

\section{Rasio perputaran kas}

James O. Gill dalam Kasmir (2019) menyatakan bahwa rasio perputaran kas (cash turnover ratio). Rasio perputaran kas adalah rasio yang berfungsi untuk menilai apakah perusahaan mampu membayar seluruh utang dan biaya yang dikeluarkan selama penjualan dengan menggunakan modal kerja yang dimiliki. Modal kerja dalam pengertian tersebut dikatakan sebagai modal kerja bersih perusahaan yang dapat ditentukan dengan mengurangi aktiva lancar terhadap utang lancar. Sementara itu, modal kerja kotor adalah jumlah dari aktiva lancar. Rumus yang digunakan untuk mencari rasio perputaran kas adalah sebagai berikut:

$$
\text { Rasio Perputaran Kas }=\frac{\text { Penjualan Bersih }}{\text { Modal Kerja Bersih }}
$$

Rasio perputaran kas (cash turnover ratio) PT. Blue Bird, Tbk sejak tahun 2016 selalu mengalami penurunan. Pada tahun 2017 rasio perputaran kas menurun cukup signifikan yaitu 57,78 kali. Rasio semula adalah 70,32 kali menjadi 12,54 kali pada tahun 2017. Penurunan juga terjadi pada tahun 2018 yaitu sebanyak 3,3 kali sehingga rasio perputaran kas tahun 2018 sebesar 9,24 kali. Meskipun terus mengalami penurunan, arus kas PT. Blue Bird, Tbk tetap positif atau tidak ada rasio yang defisit. Hal tersebut berarti perusahaan mampu menjaga keseimbangan antara net revenue dengan modal kerja bersih (current assets dikurangi current liabilities).

Tabel 3: Cash Turnover Ratio PT Blue Bird Tbk

\begin{tabular}{llrrr}
\hline \multirow{2}{*}{ No. } & \multirow{2}{*}{ Uraian } & \multicolumn{3}{c}{ Tahun } \\
\cline { 3 - 5 } & & $\mathbf{2 0 1 6}$ & \multicolumn{1}{c}{$\mathbf{2 0 1 7}$} & \multicolumn{1}{c}{$\mathbf{2 0 1 8}$} \\
\hline 1 & Net Revenues & 4.796 .096 & 4.203 .846 & 4.218 .702 \\
2 & Current Assets & 882.304 & 771.222 & 1.071 .773 \\
3 & Current Liabilities & 814.103 & 435.947 & 614.987 \\
4 & Cash Turnover & 70,32 & 12,54 & 9,24 \\
\hline
\end{tabular}

Sumber: Diolah dari laporan keuangan PT Blue Bird Tbk

Berdasarkan tabel 3, rasio perputaran kas paling besar adalah 70,32 kali pada tahun 2016. Hal tersebut menunjukkan keluar-masuknya kas yang begitu cepat dikarenakan modal kerja bersih yang terlalu rendah tetapi penjualan tergolong cukup tinggi. Meskipun begitu, pada tahun 2016 perusahaan masih mampu membayar seluruh tagihan sesuai dengan waktunya.

Pada tahun 2017 terjadi penurunan secara signifikan pada rasio perputaran kas menjadi sebesar 12,54 kali. Penurunan 
tersebut disebabkan karena perusahaan melakukan pembayaran dipercepat atas utang bank jangka pendek dan jangka panjang sehingga current liabilities menurun dan memengaruhi modal kerja bersih.

Terjadi kenaikan current assets terutama akun kas dan setara kas pada tahun 2018. Peningkatan juga terjadi pada current liabilities yaitu utang usaha dan utang pajak. Kedua hal tersebut memengaruhi modal kerja bersih tahun 2018 sehingga terjadi penurunan pada rasio perputaran kas menjadi 9,24 kali.

\section{Debt to Asset Ratio}

Menurut Kasmir (2019), Debt to asset ratio (debt ratio) merupakan salah satu rasio solvabilitas yang digunakan untuk mengukur perbandingan antara total utang dengan total aktiva. Hal tersebut berarti seberapa besar aktiva perusahaan yang dibiayai oleh utang atau seberapa besar pengelolaan aktiva dipengaruhi oleh utang perusahaan. Selanjutnya, Kasmir juga menjelaskan bahwa debt ratio yang semakin tinggi menunjukkan pendanaan yang dilakukan dengan utang semakin banyak sehingga perusahaan dikhawatirkan tidak mampu untuk melunasi utang dengan aset yang dimilikinya. Rata-rata debt to asset ratio pada industri adalah sebesar 35\%. Rumus untuk mencari debt ratio adalah sebagai berikut:

$$
\text { Debt to Asset Ratio }=\frac{\text { Total Debt }}{\text { Total Assets }}
$$

Pada tabel 4 disajikan perhitungan atas debt ratio untuk tahun 2016 hingga 2018. Berdasarkan hasil perhitungan, diketahui debt ratio perusahaan terus mengalami penurunan dalam jangka waktu tersebut yang berarti aset perusahaan yang didanai dari utang menjadi lebih sedikit dibandingkan tahun-tahun sebelumnya.

Tabel 4: Debt to Asset Ratio PT Blue Bird Tbk

\begin{tabular}{llrrr}
\hline \multirow{2}{*}{ No. } & \multirow{2}{*}{ Uraian } & \multicolumn{3}{c}{ Tahun } \\
\cline { 3 - 5 } & & $\mathbf{2 0 1 6}$ & \multicolumn{1}{c}{$\mathbf{2 0 1 7}$} & \multicolumn{1}{c}{$\mathbf{2 0 1 8}$} \\
\hline 1 & Total Debt & 2.637 .932 & 1.585 .562 & 1.689 .996 \\
2 & Total Assets & 7.300 .612 & 6.516 .487 & 6.955 .157 \\
3 & Debt to Asset Ratio $(\%)$ & $36,13 \%$ & $24,33 \%$ & $24,30 \%$ \\
\hline
\end{tabular}

Sumber: Diolah dari laporan keuangan PT Blue Bird Tbk

Pada tahun 2016, debt ratio perusahaan adalah sebesar $36,13 \%$. Hal tersebut berarti $36,13 \%$ dari seluruh aset yang dimiliki PT Blue Bird Tbk merupakan aset yang didanai dari utang atau kreditur dan sebesar $63,87 \%$ dibiayai oleh para investor perusahaan. Debt ratio tahun 2017 mengalami penurunan sebesar $11,8 \%$ dikarenakan perusahaan melakukan pelunasan dipercepat terhadap utang bank jangka pendek dan jangka panjang. Debt ratio pada akhir tahun 2017 adalah 24,33\% yang menunjukkan bahwa sebesar 24,33\% dari total assets dibiayai dengan utang dan $75,67 \%$ sisanya dibiayai oleh investor. Hal ini menunjukkan kondisi perusahaan yang membaik dibandingkan tahun 2016. Sementara itu, tahun 2018 terjadi penurunan pada debt ratio sebesar $0,03 \%$ dikarenakan terdapat kenaikan pada aset lancar dan pembelian aset tetap selama tahun tersebut. Debt ratio pada akhir tahun 2018 adalah 24,3\%, yang berarti 24,3\% dari seluruh aset perusahaan dibiayai 
melalui utang dan $75,7 \%$ dibiayai oleh investor.

\section{Debt to equity ratio.}

Pengertian debt to equity ratio menurut Kasmir (2019) adalah rasio yang bertujuan untuk mengetahui banyaknya dana yang diperoleh dari kreditur dan pemilik perusahaan yang didapat dengan melakukan perbandingan antara total utang dengan total ekuitas perusahaan. Rasio rata-rata industri untuk debt to equity ratio adalah sebesar $90 \%$.
Bagi kreditur, semakin tinggi rasio maka risiko yang ditanggung atas kemungkinan kegagalan yang terjadi di perusahaan akan semakin besar. Sebaliknya, rasio yang tinggi bagi perusahaan menunjukkan semakin rendah pendanaan (modal sendiri) yang disediakan pemilik untuk membiayai aktiva jika terjadi penyusutan atau kerugian terhadap nilai aktiva. Rumus untuk menentukan debt to equity ratio adalah sebagai berikut:

$$
\text { Debt to Equity Ratio }=\frac{\text { Total Debt }}{\text { Total Equity }}
$$

Pada tabel 5 disajikan perhitungan atas debt to equity ratio untuk tahun 2016 hingga 2018. Berdasarkan hasil perhitungan, diketahui debt to equity ratio perusahaan terus mengalami penurunan dalam jangka waktu tersebut. Hal itu berarti komposisi kenaikan pada ekuitas total lebih tinggi dibandingkan dengan total kewajiban sehingga beban perusahaan terhadap kreditor semakin kecil.

Tabel 5: Debt to Equity Ratio PT Blue Bird Tbk

\begin{tabular}{rrrrr}
\hline \multirow{2}{*}{ No. } & \multirow{2}{*}{ Uraian } & \multicolumn{3}{c}{ Tahun } \\
\cline { 3 - 5 } & & $\mathbf{2 0 1 6}$ & \multicolumn{1}{c}{$\mathbf{2 0 1 7}$} & \multicolumn{1}{c}{$\mathbf{2 0 1 8}$} \\
\hline 1 & EBIT & 478.653 & 429.446 & 540.692 \\
2 & Biaya Bunga & 213.158 & 132.731 & 65.483 \\
3 & Times Interest Earned $(\mathrm{X})$ & 2,25 & 3,24 & 8,26 \\
\hline
\end{tabular}

Sumber: Diolah dari laporan keuangan PT Blue Bird Tbk

Berdasarkan perhitungan, debt to equity ratio tahun 2016 cukup besar dibandingkan dengan tahun 2017 dan 2018 yaitu $56,58 \%$. Hal tersebut berarti total utang yang dimiliki perusahaan adalah sebesar $56,58 \%$ dari total ekuitas atau modal perusahaan. Pada tahun 2017 terjadi penurunan debt to equity ratio menjadi $32,16 \%$ yang berarti total utang perusahaan adalah $32,16 \%$ dari ekuitas yang dimiliki. Penurunan tersebut dikarenakan perusahaan melakukan pembayaran dipercepat atas utang bank jangka pendek dan jangka panjang. Selain itu, juga disebabkan oleh meningkatnya saldo laba pada tahun 2017. Hal tersebut menunjukkan bahwa kinerja perusahaan dalam menangani utang lebih baik dibandingkan tahun 2016.

Penurunan kembali terjadi pada tahun 2018 meskipun tidak signifikan. Debt to equity ratio 2018 adalah 32,1\% yang berarti total utang yang dimiliki perusahaan adalah $32,1 \%$ dari total ekuitasnya. Pada tahun tersebut terjadi peningkatan pada total liabilitas dan saldo laba, tetapi peningkatan saldo laba lebih tinggi dibandingkan total liabilitas sehingga menyebabkan penurunan pada debt to equity ratio.

\section{Times interest earned}

Kasmir (2019) menyatakan bahwa times interest earned merupakan rasio 
untuk mengetahui jumlah kali perolehan bunga. Serupa dengan coverage ratio, rasio ini digunakan sebagai pengukur kapabilitas perusahaan dalam melunasi biaya bunga. Secara umum, jika rasio makin tinggi, maka semakin besar kemungkinan perusahaan dapat membayar bunga pinjaman dan dapat menjadi acuan untuk memperoleh tambahan pinjaman dari kreditur. Kasmir (2019) menyatakan bahwa standar industri untuk times interest earned adalah sebanyak sepuluh (10) kali. Untuk mengetahui rasio ini dapat digunakan rumus:

$$
\text { Times Interest Earned }=\frac{\text { Earnings Before Interest and Tax }}{\text { Biaya Bunga }}
$$

Berdasarkan perhitungan yang telah dilakukan dan tersaji pada tabel 6, Times Interest Earned (TIER) PT Blue Bird Tbk selalu mengalami kenaikan selama tahun 2016 hingga tahun 2018. Hal tersebut menunjukkan bahwa kemampuan PT. Blue Bird, Tbk dalam membayar biaya bunga pinjaman semakin membaik pada setiap tahunnya.

Tabel 6: Times Interest Earned PT Blue Bird Tbk

\begin{tabular}{llrrr}
\hline \multirow{2}{*}{ No. } & \multirow{2}{*}{ Uraian } & \multicolumn{3}{c}{ Tahun } \\
\cline { 3 - 5 } & Total Debt & 2.637 .932 & 1.585 .562 & 1.689 .996 \\
\hline 1 & Total Equity & 4.662 .680 & 4.930 .925 & 5.265 .161 \\
3 & Debt to Equity Ratio $(\%)$ & $56,58 \%$ & $32,16 \%$ & $32,10 \%$ \\
\hline
\end{tabular}

\section{Sumber: Diolah dari laporan keuangan PT Blue Bird Tbk}

Pada tahun 2016, hasil perhitungan TIER perusahaan adalah 2,25 kali. Hal tersebut dapat diartikan bahwa biaya bunga pinjaman dapat ditutup 2,25 kali laba sebelum bunga dan pajak (EBIT). Rasio pada 2016 tergolong kecil karena biaya bunga yang ditanggung PT. Blue Bird, Tbk cukup besar pada tahun tersebut.

Tahun berikutnya, TIER PT. Blue Bird, Tbk mulai mengalami kenaikan menjadi 3,24 kali. Pada tahun 2017 terjadi pembayaran atas utang bank jangka pendek dan jangka panjang sehingga mengurangi total utang dan biaya bunga. Hal tersebut menyebabkan terjadinya kenaikan pada TIER 2017 dan sebagai indikator bahwa terdapat peningkatan pada kemampuan PT.
Blue Bird, Tbk dalam membayar beban bunga pinjaman.

\section{Perputaran aktiva tetap}

Perputaran aktiva tetap (fixed assets turnover) merupakan rasio yang mengukur berapa kali dana yang ditanamkan dalam fixed assets berputar dalam satu periode dan juga menilai berapa jumlah pendapatan yang dihasilkan dari tiap rupiah aktiva tetap tersebut. Pada tabel 7 disajikan perhitungan atas perputaran aktiva tetap PT Blue Bird Tbk tahun 2016 hingga 2018. Berdasarkan tabel tersebut dapat diketahui bahwa perputaran aktiva tetap perusahaan selalu mengalami penurunan yang tidak signifikan. 
Tabel 7: Fixed Assets Turnover PT Blue Bird Tbk

\begin{tabular}{|c|c|c|c|c|}
\hline \multirow{2}{*}{ No. } & \multirow{2}{*}{ Uraian } & \multicolumn{3}{|c|}{ Tahun } \\
\hline & & 2016 & 2017 & 2018 \\
\hline 1 & Sales & 4.796 .096 & 4.203 .846 & 4.218 .702 \\
\hline 2 & Total Fixed Assets & 6.185 .247 & 5.605 .524 & 5.724 .503 \\
\hline 3 & Fixed Assets Turnover (X) & 0,78 & 0,75 & 0,74 \\
\hline
\end{tabular}

Sumber: Diolah dari laporan keuangan PT Blue Bird Tbk

Perputaran aktiva tetap pada tahun 2016 berdasarkan perhitungan adalah sebanyak 0,78 kali. Hal tersebut berarti dari setiap Rp1 aktiva tetap yang digunakan, PT. Blue Bird, Tbk mampu menghasilkan penjualan sebesar Rp0,78. Pada tahun 2017 perputaran aktiva tetap turun menjadi 0,75 kali yang dapat diartikan bahwa PT. Blue Bird, Tbk mampu menghasilkan Rp0,75 penjualan dari setiap Rp1 aktiva tetap yang beroperasi. Perputaran aktiva tetap juga mengalami penurunan pada tahun 2018 menjadi 0,74 kali. Hal tersebut mengindikasikan bahwa perusahaan belum mampu memanfaatkan aktiva tetap yang dimilikinya secara efisien dalam menghasilkan penjualan.

\section{Perputaran aktiva}

Perputaran aktiva (total assets turnover) merupakan rasio yang mengukur perputaran seluruh aktiva yang dimiliki perusahaan dan mengukur berapa jumlah penjualan yang diperoleh dari tiap rupiah aktiva tersebut. Perhitungan atas perputaran aktiva PT Blue Bird Tbk pada periode 2016 s.d. 2018 tertera pada tabel 8 . Terlihat bahwa pada periode tersebut perputaran aktiva selalu mengalami penurunan meskipun tidak signifikan.

Tabel 8: Total Assets Turnover PT Blue Bird Tbk

\begin{tabular}{|c|c|c|c|c|}
\hline \multirow{2}{*}{ No. } & \multirow{2}{*}{ Uraian } & \multicolumn{3}{|c|}{ Tahun } \\
\hline & & 2016 & 2017 & 2018 \\
\hline 1 & Sales & 4.796 .096 & 4.203 .846 & 4.218 .702 \\
\hline 2 & Total Assets & 7.300 .612 & 6.516 .487 & 6.955 .157 \\
\hline 3 & Total Assets Turnover (X) & 0,66 & 0,65 & 0,61 \\
\hline
\end{tabular}

Sumber: Diolah dari laporan keuangan PT Blue Bird Tbk

Pada tahun 2016, perputaran aktiva adalah sebanyak 0,66 kali yang berarti setiap Rp1 aktiva mampu menghasilkan Rp0,66 penjualan. Kemudian, perputaran aktiva pada tahun 2017 menjadi 0,65 kali yang menandakan terjadi penurunan kemampuan perusahaan dalam menghasilkan penjualan dari seluruh aktiva yang dimilikinya. Penurunan perputaran aktiva juga terjadi pada tahun 2018 yaitu menjadi sebanyak 0,61 kali. Hal tersebut berarti PT. Blue Bird, Tbk hanya mampu menghasilkan $\mathrm{Rp} 0,61$ penjualan dari Rp1 total aktiva yang dimilikinya.

\section{Margin laba kotor}

Margin laba kotor (Gross profit margin) menunjukkan perbandingan antara laba kotor dengan total pendapatan neto perusahaan. Pada tabel 9 tertera perhitungan gross profit margin PT Blue Bird Tbk yang menunjukkan adanya kenaikan dan penurunan pada periode 2016 s.d. 2018. 
Tabel 9: Gross Profit Margin PT Blue Bird Tbk

\begin{tabular}{clrrr}
\hline \multirow{2}{*}{ No. } & \multirow{2}{*}{ Uraian } & \multicolumn{3}{c}{ Tahun } \\
\cline { 3 - 5 } & & $\mathbf{2 0 1 6}$ & $\mathbf{2 0 1 7}$ & \multicolumn{1}{c}{$\mathbf{2 0 1 8}$} \\
\hline 1 & Gross Profit & 1.369 .893 & 1.137 .835 & 1.179 .549 \\
2 & Net Revenue & 4.796 .096 & 4.203 .846 & 4.218 .702 \\
3 & Gross Profit Margin $(\%)$ & $28,56 \%$ & $27,07 \%$ & $27,96 \%$ \\
\hline
\end{tabular}

Sumber: Diolah dari laporan keuangan PT Blue Bird Tbk

Pada tahun 2016, gross profit margin terhitung sebesar $28,56 \%$. Rasio tersebut menurun sebanyak $1,5 \%$ pada tahun 2017 menjadi $27,07 \%$. Hal tersebut disebabkan oleh terjadinya penurunan gross profit karena menurunnya pendapatan neto perusahaan meskipun beban langsung yang dikeluarkan juga lebih sedikit dibandingkan tahun 2016. Gross profit margin meningkat pada tahun 2018, meskipun tidak signifikan, yaitu menjadi sebesar 27,96\%. Kenaikan tersebut menandakan perusahaan telah lebih efisien dalam kegiatan penjualannya karena mampu menghasilkan pendapatan neto yang lebih tinggi dan mengendalikan beban langsung secara bersamaan.

\section{Margin laba bersih}

Margin laba bersih (net profit margin) menunjukkan perbandingan antara Earnings After Interest and Tax (EAIT) dengan total pendapatan neto perusahaan. Pada tabel 10 tertera perhitungan net profit margin PT Blue Bird Tbk yang menunjukkan adanya kenaikan dan penurunan pada periode 2016 s.d. 2018.

Tabel 10: Net Profit Margin PT Blue Bird Tbk

\begin{tabular}{clrrr}
\hline \multirow{2}{*}{ No. } & \multirow{2}{*}{ Uraian } & \multicolumn{3}{c}{ Tahun } \\
\cline { 3 - 5 } & & $\mathbf{2 0 1 6}$ & $\mathbf{2 0 1 7}$ & \multicolumn{1}{c}{$\mathbf{2 0 1 8}$} \\
\hline 1 & EAIT & 500.871 & 421.735 & 462.544 \\
2 & Net Revenue & 4.796 .096 & 4.203 .846 & 4.218 .702 \\
3 & Net Profit Margin $(\%)$ & $10,44 \%$ & $10,03 \%$ & $10,96 \%$ \\
\hline
\end{tabular}

Sumber: Diolah dari laporan keuangan PT Blue Bird Tbk

Net profit margin tahun 2016 adalah sebesar $10,44 \%$. Rasio tersebut menurun sebanyak $0,41 \%$ pada tahun 2017 menjadi $10,03 \%$. Hal tersebut terjadi karena menurunnya net profit yang berasal dari penurunan pendapatan neto PT. Blue Bird, Tbk, tetapi beban usaha yang harus dibayar selama tahun 2017 lebih besar dibandingkan tahun 2016. Terdapat kenaikan pada net profit margin tahun 2018 menjadi sebesar 10,96\%. Kenaikan itu dipicu karena adanya peningkatan pada pendapatan neto dan menurunnya beban langsung yang dikeluarkan selama 2018.
Hal tersebut menandakan perusahaan lebih efisien dalam mengelola biaya-biaya yang berhubungan dengan kegiatan operasinya.

\section{Return on investment}

Return on investment atau return on assets merupakan rasio yang menunjukkan seberapa besar return atas jumlah aset yang digunakan dalam perusahaan. Perhitungan return of investment PT Blue Bird Tbk tahun 2016 s.d. 2018 dapat dilihat pada tabel 11. Terlihat terjadinya kenaikan dan penurunan selama tiga tahun tersebut. 
Tabel 11: Return on Investment PT Blue Bird Tbk

\begin{tabular}{rrrrr}
\hline \multirow{2}{*}{ No. } & \multirow{2}{*}{ Uraian } & \multicolumn{3}{c}{ Tahun } \\
\cline { 3 - 5 } & & \multicolumn{1}{c}{$\mathbf{2 0 1 6}$} & \multicolumn{1}{c}{$\mathbf{2 0 1 7}$} & \multicolumn{1}{c}{$\mathbf{2 0 1 8}$} \\
\hline 1 & EAIT & 500.871 & 421.735 & 462.544 \\
2 & Total Assets & 7.300 .612 & 6.516 .487 & 6.955 .157 \\
3 & ROI $(\%)$ & $6,86 \%$ & $6,47 \%$ & $6,65 \%$ \\
\hline
\end{tabular}

Sumber: Diolah dari laporan keuangan PT Blue Bird Tbk

Pada tahun 2016, return on investment terhitung sebesar $6,86 \%$. Hal tersebut berarti setiap Rp1 total aset yang dimiliki oleh perusahaan akan menghasilkan Rp0,0686 laba bersih setelah pajak. Kemudian, terjadi penurunan pada return on investment tahun 2017 menjadi $6,47 \%$. Hal tersebut menandakan adanya penurunan kemampuan perusahaan dalam menghasilkan pendapatan dari jumlah aset yang digunakan.

Peningkatan atas kemampuan perusahaan menghasilkan pendapatan dari total aset yang digunakan meningkat pada tahun 2018. Hal tersebut tercermin dari return on investment yang naik menjadi $6,65 \%$ dengan arti bahwa perusahaan mampu menghasilkan laba bersih setelah pajak sebesar Rp 0,0665 dari setiap Rp1 total aset yang digunakan.

\section{Return on equity}

Return on equity merupakan rasio yang menunjukkan seberapa efisien perusahaan dalam menggunakan modal sendiri (total ekuitas). Perhitungan return of equity PT Blue Bird Tbk tahun 2016 s.d. 2018 dapat dilihat pada tabel 12. Terlihat terjadinya kenaikan dan penurunan selama tiga tahun tersebut.

Tabel 12: Return on Equity PT Blue Bird Tbk

\begin{tabular}{rlrrr}
\hline \multirow{2}{*}{ No. } & & Uraian & \multicolumn{3}{c}{ Tahun } \\
\cline { 3 - 5 } & & $\mathbf{2 0 1 6}$ & \multicolumn{1}{c}{$\mathbf{2 0 1 7}$} & \multicolumn{1}{c}{$\mathbf{2 0 1 8}$} \\
\hline 1 & EAIT & 500.871 & 421.735 & 462.544 \\
2 & Total Equity & 4.662 .680 & 4.930 .925 & 5.265 .161 \\
3 & ROE $(\%)$ & $10,74 \%$ & $8,55 \%$ & $8,78 \%$ \\
\hline
\end{tabular}

Sumber: Diolah dari laporan keuangan PT Blue Bird Tbk

Berdasarkan perhitungan, return on equity tahun 2016 adalah 10,74\% yang berarti dari setiap Rp1 total modal sendiri yang dimiliki, perusahaan mampu menghasilkan laba bersih setelah pajak sebesar Rp0,1074. Pada tahun 2017 perusahaan mengalami penurunan return on equity menjadi $8,55 \%$. Hal tersebut mengindikasikan menurunnya tingkat efisiensi perusahaan dalam menggunakan total ekuitas yang dimilikinya.
Return on equity mulai mengalami kenaikan yang tidak terlalu signifikan pada tahun 2018 yaitu menjadi sebesar 8,78\%. Kenaikan tersebut menandakan bahwa perusahaan sudah semakin efisien dalam memanfaatkan total ekuitas yang dimilikinya. Pada tahun 2018 perusahaan mampu menghasilkan Rp0,0878 laba bersih setelah pajak dari setiap Rp1 total ekuitas. 


\section{METODE PENELITIAN}

Metode penelitian yang digunakan adalah melalui pendekatan kuantitatif. Penelitian kuantitatif menurut Kasiram (2008) adalah proses memperoleh suatu informasi dengan menggunakan data berupa angka sebagai alat untuk menganalisis keterangan atau data menjadi informasi. Hal ini sejalan dengan pernyataan Santosa dan Ashari (2005), bahwa data kuantitatif merupakan data berwujud angka atau bilangan yang umumnya diolah menggunakan teknik perhitungan matematika. Data kuantitatif terdiri atas nominal, ordinal, interval, dan rasio. Untuk mendukung penelitian tersebut, digunakan metode pengumpulan data yaitu studi kepustakaan. Studi kepustakaan adalah dengan membaca, mempelajari, dan memahami materi terkait yang didapat dari buku, jurnal, artikel, website, standar akuntansi yang ditetapkan, materi kuliah, dan sumber lain yang relevan. Metode ini bertujuan untuk memperoleh pemahaman yang memadai mengenai materi yang akan dibahas. Data yang digunakan berupa laporan keuangan PT. Blue Bird, Tbk yang meliputi laporan neraca dan laba-rugi periode 2016-2018.

Metode analisis data yang digunakan, adalah dengan mengolah data yang telah diperoleh dari laporan keuangan tahunan PT Blue Bird Tbk periode 2016-2018. Laporan keuangan tersebut menjadi sumber informasi untuk menganalisis rasio keuangan, selanjutnya data-data tersebut dibandingkan dan dihubungkan antara satu dengan lainnya.

\section{PEMBAHASAN}

Jika dikaitkan dengan teori yang telah dibahas, standar rasio lancar yang dianggap baik atau memuaskan bagi perusahaan adalah sebesar $200 \%$ atau perbandingannya 2:1. Dari hasil analisis, dapat diketahui bahwa pada tahun 2016 hingga tahun 2018, rasio lancar PT Blue
Bird Tbk masih berada di bawah standar tersebut. Rasio paling kecil terjadi pada tahun 2016 saat kemampuan perusahaan dalam menutup kewajiban jangka pendek dengan aktiva lancar sangat rendah. Namun, pada tahun 2017 dan 2018 kemampuan perusahaan membayar kewajiban lancar sudah mulai membaik dengan rasio lancar yang semakin mendekati standar yang ada.

Mengacu pada teori, standar rata-rata industri untuk cash ratio adalah sebesar 50\% sehingga pada tahun 2016 hingga 2018 kemampuan PT. Blue Bird, Tbk dalam membayar utang lancar menggunakan kas dan setara kas dapat dikatakan baik dan berada di atas rata-rata industri. Namun, rasio yang terlalu tinggi seperti pada tahun 2017 dan 2018 juga dapat menjadi indikasi bahwa manajemen belum mengelola kas dan setara kas dengan baik. Hal itu memunculkan kemungkinan adanya kas yang menganggur (idle cash) dan belum digunakan secara optimal.

Berdasarkan teori, rata-rata industri untuk rasio perputaran kas adalah sepuluh (10) kali sehingga dapat disimpulkan perusahaan belum mampu memenuhi standar industri selama tahun 2016 hingga 2018. Pada tahun 2016 rasio perputaran kas cukup tinggi dibandingkan dengan industri yang berarti keluar-masuknya kas begitu cepat. Kemudian, pada tahun 2017 rasio perputaran kas mulai mendekati standar industri sehingga kemampuan perusahaan membayar seluruh tagihan sesuai waktunya semakin membaik. Pada tahun 2018 rasio perputaran kas lebih rendah dibandingkan standar yang berarti kas lebih banyak tertanam pada aktiva yang sulit dicairkan dalam waktu singkat dan kas yang dimiliki perusahaan lebih sedikit dibandingkan tahun-tahun sebelumnya.

Mengacu pada teori, rata-rata industri untuk debt ratio adalah $35 \%$. Semakin rendah debt ratio, maka persentase perusahaan dibiayai oleh kreditur melalui utang adalah semakin kecil. Secara keseluruhan, debt ratio $\mathrm{PT}$. 
Blue Bird, Tbk dapat dikatakan bagus walaupun pada tahun 2016 rasionya lebih tinggi dari rata-rata industri, tetapi tidak signifikan. Oleh karena itu, dapat disimpulkan bahwa dalam membiayai aktiva yang dimilikinya, PT Blue Bird Tbk cenderung menggunakan dana yang diperoleh dari investor dibandingkan dari utang atau kreditur.

Mengacu pada teori rata-rata industri untuk debt to equity ratio yang sebesar $90 \%$, maka dapat disimpulkan bahwa keadaan PT Blue Bird Tbk lebih baik dibandingkan industri. Hal tersebut berarti beban perusahaan terhadap kreditor lebih kecil.

TIER perusahaan kembali mengalami kenaikan pada tahun 2018 menjadi 8,26 kali. Kenaikan tersebut disebabkan karena PT. Blue Bird, Tbk berhasil meminimalkan beban langsung sehingga laba sebelum bunga dan pajak yang dihasilkan lebih besar. Selain itu, biaya bunga juga lebih rendah dibandingkan tahun-tahun sebelumnya karena perusahaan melakukan pelunasan atas pinjaman bank. Pada tahun 2018 kemampuan perusahaan dalam membayar beban bunga pinjaman meningkat dibanding tahun sebelumnya.

Berdasarkan teori yang telah dibahas, TIER PT Blue Bird Tbk pada tahun 2016 dan 2017 masih jauh di bawah rata-rata industri yang sebesar sepuluh (10) kali. Hal tersebut menunjukkan kemampuan perusahaan dalam membayar beban bunga berada di bawah rata-rata industri. Namun pada tahun 2018, kondisi perusahaan sudah mulai membaik karena TIER yang dihasilkan sudah cukup mendekati standar industri, yang berarti perusahaan semakin mampu membayar beban bunga dan dapat dijadikan acuan untuk memperoleh tambahan pinjaman dari kreditur.

Untuk perputaran aktiva tetap, ratarata industri yang tertera pada teori adalah sebesar lima (5) kali. Berdasarkan hal tersebut dapat dikatakan bahwa kondisi PT
Blue Bird Tbk yang dinilai berdasarkan perputaran aktiva tetap sedang tidak baik karena pemanfaatan aktiva tetap untuk menghasilkan penjualan belum efektif.

Berdasarkan teori yang telah dibahas, rata-rata industri untuk perputaran aktiva adalah sebanyak dua (2) kali. Oleh karena itu, dapat dikatakan bahwa selama 2016 hingga 2018 PT Blue Bird Tbk belum mampu memenuhi standar perputaran aktiva dikarenakan masih belum efisien dalam mengelola total aktiva yang dimiliki untuk menghasilkan penjualan.

Jika dikaitkan dengan teori, rata-rata industri untuk gross profit margin adalah sebesar $30 \%$ sehingga dapat ditarik kesimpulan bahwa pada periode 2016 s.d. 2018 PT Blue Bird Tbk masih belum mampu mengelola pengeluaran terkait beban langsung secara efisien yang tercermin dari gross profit margin yang masih berada di bawah rata-rata industri.

Berdasarkan teori, net profit margin PT Blue Bird Tbk selama 2016 hingga 2018 masih berada di bawah rata-rata industri yang sebesar 20\%. Hal tersebut berarti kemampuan perusahaan dalam mengelola biaya-biaya terkait kegiatan operasional masih belum baik dan belum efisien dibandingkan dengan industri serupa.

Berdasarkan teori, jika dilihat dari rata-rata industri untuk return on investment yang sebesar 30\%, maka dapat disimpulkan bahwa kondisi PT Blue Bird Tbk yang dinilai berdasarkan return on investment masih kurang baik karena perusahaan masih belum mampu secara efektif mengelola total aset yang dimiliki untuk memperoleh return.

Berdasarkan teori yang telah dibahas, return on equity dapat dikatakan baik jika mampu memenuhi standar industri yaitu sebesar $40 \%$. Karena selama tahun 2016 hingga tahun 2018 return on equity PT Blue Bird Tbk belum ada yang mendekati $40 \%$, maka dapat disimpulkan bahwa tingkat efisiensi penggunaan ekuitas untuk menghasilkan laba bersih 
setelah pajak masih rendah dan berada di bawah rata-rata industri.

\section{KESIMPULAN DAN SARAN}

\section{Kesimpulan}

Berdasarkan hasil penelitian dan pembahasan terhadap laporan keuangan PT Blue Bird Tbk periode 2016 s.d. 2018, dapat diambil kesimpulan atas perhitungan rasio likuiditas, solvabilitas, aktivitas, dan profitabilitas sebagai berikut: 1). Berdasarkan analisis likuiditas yaitu current ratio, cash ratio, dan cash turnover ratio pada tahun 2016 dapat dinyatakan bahwa PT Blue Bird Tbk masih belum memenuhi kriteria rata-rata rasio industri. Namun, untuk tahun 2017 dan 2018, perusahaan sudah cukup mampu memenuhi kriteria rasio industri khususnya cash ratio, sehingga secara keseluruhan kemampuan likuiditas perusahaan dapat dikatakan cukup baik dan mampu untuk memenuhi kewajiban lancarnya dengan aktiva lancar. 2). Secara keseluruhan tingkat solvabilitas dari tahun 2016 s.d. 2018 yang diukur melalui indikator debt to asset ratio, debt to equity ratio, dan times interest earned ratio sudah dapat dikatakan dalam posisi yang baik terutama pada tahun 2018. Namun, rasio solvabilitas melalui debt to asset ratio, untuk tahun 2016 PT Blue Bird Tbk belum mampu memenuhi standar industri walaupun selisihnya tidak signifikan. Sementara itu, untuk tahun 2017 dan 2018, debt to asset ratio perusahaan sudah memenuhi standar industri. Artinya, dalam pembiayaan aktiva, PT Blue Bird Tbk cenderung menggunakan dana yang diperoleh dari investor dibandingkan dari kreditur. 3). Untuk rasio solvabilitas melalui debt to equity ratio periode tahun 2016-2018, keadaan PT Blue Bird Tbk lebih baik dibandingkan dengan rata-rata industri dikarenakan lebih rendah dari 90\%. Hal ini disimpulkan bahwa beban atas utang yang ditanggung perusahaan terhadap kreditor lebih kecil dibandingkan rata-rata industri.
4). Berdasarkan times interest earned ratio periode 2016-2018, PT Blue Bird Tbk masih belum memenuhi standar. Hal tersebut mengindikasikan bahwa kemampuan perusahaan dalam membayar beban bunga berada di bawah rata-rata industri. Namun, rasio pada tahun 2018 sudah mulai mendekati standar industri, yang berarti kemampuan perusahaan membayar beban bunga semakin baik. 5). Untuk rasio aktivitas yang diukur melalui indikator fixed assets turnover dan total assets turnover, kedua indikator tersebut masih berada di bawah standar dan terus menurun untuk periode 2016-2018. Hal ini menunjukkan bahwa PT Blue Bird Tbk masih belum bisa dikatakan efisien dalam pemanfaatan aktiva tetap dan total aktiva untuk memperoleh pendapatan dibandingkan dengan rata-rata industri. 6). Untuk tingkat profitabilitas PT Blue Bird Tbk tahun 2016 s.d. 2018 yang dinilai berdasarkan indikator gross profit margin, net profit margin, return on investment, dan return on equity dapat dikatakan pada kondisi yang kurang baik karena keempat indikator tersebut belum ada yang mampu memenuhi standar. 7). Berdasarkan gross profit margin dan net profit margin tahun 2016 hingga 2018, PT Blue Bird Tbk masih belum mampu memenuhi standar industri sehingga dapat dikatakan tingkat profitabilitas perusahaan berada pada kondisi kurang baik. Kondisi profitabilitas perusahaan dinilai dari kedua indikator tersebut paling baik terjadi pada tahun 2016, sedangkan paling buruk adalah pada tahun 2017 karena profit dan revenue yang dihasilkan sangat kecil. 8). Menurut indikator return on investment dan return on equity untuk periode tahun 2016-2018, PT Blue Bird Tbk belum mampu memenuhi rasio rata-rata industri. Terutama pada tahun 2017, return on investment dan return on equity terhitung sangat kecil. Hal tersebut menandakan bahwa perusahaan masih belum mampu memanfaatkan total aset dan total ekuitas yang dimilikinya secara efisien untuk 
menghasilkan penjualan. 9). Berdasarkan analisis, dapat diambil kesimpulan bahwa pada periode 2016 hingga 2018 kondisi PT Blue Bird Tbk yang dinilai berdasarkan rasio likuiditas dan solvabilitas dapat dikatakan cukup baik. Namun, jika dilihat dari rasio aktivitas dan profitabilitas, perusahaan berada dalam posisi yang kurang baik dibandingkan rata-rata industri.

\section{Saran}

1. Berdasarkan indikator likuiditas, untuk meningkatkan kinerja perusahaan pada indikator ini PT Blue Bird Tbk seyogyanya meningkatkan aset lancar yang dimiliki dan mengurangi kewajiban lancar dengan melakukan pembayaran secara tepat waktu. Kemudian, untuk kas dan setara kas, perusahaan hendaknya mempergunakannya dengan lebih efektif agar tidak ada kas yang menganggur (idle cash).

2. Berdasarkan indikator solvabilitas, kinerja PT Blue Bird Tbk sudah tergolong cukup baik, tetapi hendaknya perusahaan mampu mengurangi utang yang dimiliki dan juga meningkatkan total aktivanya.

3. Untuk meningkatkan kinerja pada indikator aktivitas, PT Blue Bird Tbk hendaknya lebih efisien dalam pemanfaatan aktiva tetap dan total aktiva yang dimiliki agar mampu menghasilkan penjualan yang maksimal.

4. Dilihat dari indikator profitabilitas, PT Blue Bird Tbk hendaknya mampu meningkatkan penjualan dengan terus melakukan inovasi agar mampu bertahan di pasar. Selain itu perusahaan juga hendaknya melakukan kontrol atas beban-beban operasional yang dikeluarkan dalam rangka meningkatkan profit.

\section{DAFTAR PUSTAKA}

Goni, Marchel R. A., Dolina L. Tampi, dan Wilfred S. Manopo. 2019. Analisis Rasio Keuangan pada PT Bluebird Tbk Setelah Adanya Sarana Transportasi Berbasis Online. Jurnal Administrasi Bisnis 8, no. 1: 71-78. https://doi.org/10. 35797/jab.8.1.2019.23502.71-78 (diakses 23 Desember 2019).

Kasiram, M. (2008). Metode Penelitian Kualitatif dan kuantitatif Malang: UIN Press.

Kasmir. 2019. Analisis Laporan Keuangan. Edisi Revisi 2019. Jakarta: PT RajaGrafindo Persada.

Santosa, Purbayu Budi dan Ashari. 2005. Analisis Statistik dengan Microsoft Excel \& SPSS. Yogyakarta: Penerbit Andi. 